\title{
Swimming Pool Water in Mafraq City in Northern Jordan: Quality Evaluation
}

\author{
Sura Taha Al-Harahsheh \\ $\mathrm{Al}$ al-Bayt University, Institute of Earth and Environmental Sciences, Mafraq, Jordan \\ †Corresponding author: Sura Taha Al-Harahsheh; sura@aabu.edu.jo
}

Nat. Env. \& Poll. Tech.

Website: www.neptjournal.com

Received: 26-01-2020

Revised: $17-02-2020$

Accepted: 16-04-2020

Key Words:

Swimming pools

Water quality

Residual chlorine

Total organic carbon

Trihalomethane

Total coliforms

\begin{abstract}
The objective of this study is to examine the physical, chemical and biological characteristics of swimming pool water in Mafraq city, north of Jordan and the overall quality of the used water. Three public swimming pools were selected from Mafraq city [Areef Pool (SW1), Teachers Club Pool (SW2) and Anakeel Pool (SW3)] to analyze the physical, chemical and biological properties of their water as well as determine their compliance with the Jordanian Standards for Swimming Pools Water. Sampling was carried out weekly for eight successive weeks between July and August 2019 before bathing (after disinfection) and after bathing and analysed in Al al-Bayt University and Ministry of Environment laboratories. The parameters used to evaluate the quality of water in swimming pools were temperature, $\mathrm{pH}$, electrical conductivity (EC), dissolved oxygen (DO), residual chlorine $\left(\mathrm{Cl}_{2}\right)$, total organic carbon (TOC), trihalomethanes (THM), major cations and anions, selected heavy metals, and total coliform bacteria, E. coli and Pseudomonas. Most of the physical and chemical parameters analysed were within the recommended limit except for $\mathrm{pH}$ and EC. Residual chlorine exceeded the permissible limits in SW3 before and after bathing, recording mean values of $\mathrm{pH}, \mathrm{EC}(4.3 \pm 0.25-4.33 \pm 0.44),(2314$ $\pm 343-2453 \pm 460$ ), respectively. The dissolved oxygen was less than the recommended limit. Total coliforms, E. coli and Pseudomonas counts were $<1$ before and after bathing in all the samples.
\end{abstract}

\section{INTRODUCTION}

Swimming is one of the best sports that people of all ages can practice in their lives to maintain good health, especially for children with asthma. This is because inhaling moist air is less conductive to triggering exercise-induced asthma (Nemery et al. 2002).

Swimming pools are used by a wide range of people of various ages, health statuses and standards of hygiene (Public and Environment Health 1998). The water in swimming pools contains many microorganisms and undesirable dissolved chemical substances from several sources, including swimmers, animals, and debris like leaves, grass and dust (Popadopoulou et al. 2008). It contains many undesirable pollutants, such as skin cells, urine, sweat, saliva, ammonia, nose and throat secretions, and cosmetics. Urine and sweat are the most important components of swimming pools, and their presence spreads diseases and infections linked to the faecal contamination of water.

The increased concentration of some ions originating from pollutants, such as nitrates and phosphates, leads to algal growth. As the algae die, it decomposes and consume the dissolved oxygen in the water. This creates an anaerobic reaction that forms substances like acid, methane gas, and some harmful organic compounds.
These pollutants in swimming-pool water are removed via several physical and chemical methods, such as filtration, algaecides, disinfection, coagulants, acids and alkalis, and balancing the water $\mathrm{pH}$.

One mechanical method for cleaning swimming-pool water is filtration, in which a filter removes virtually all particulate matter, so the water remains clear enough for continued use in the pool. Algaecide $\left(\mathrm{C}_{5} \mathrm{H}_{12} \mathrm{NOCl}\right)$, which is cationic, polymeric, and non-foaming, is used in swimming pools to control the growth of algal bloom and slime. After the use of algaecide, the pool water is filtered quickly to prevent the algae from depositing (www.ikingnod.com) ( https://www. okchem.com/product/nndimethyl2hydroxypropylammonium-chloride-polymer-25988970-201811051257620.html)

Disinfection is the most important way to remove pathogens from swimming pools and minimize the risk to pool users from microbial contaminants. It involves adding chlorine gas or its derivatives, such as sodium hypochlorite, calcium hypochlorite, chloroisocyanurate, or trichloroisocyanuric acids (Yan et al. 2018).

One problem associated with the disinfection of water using a chlorine product is the accumulation of potentially toxic and disinfection by-products (DBPs) that result from the reaction of chlorine with organic matter, such as humic 
and fulvic acids, which include chloramines, trihalomethanes (THMs), and haloacetic acids (HAAs) (Lempart et al. 2018, Chowdhury et al. 2014). Coagulants may be added as part of the water treatment process to enhance the removal of dissolved, colloidal, or suspended material. Acids and alkalis may also be added to the water to maintain an appropriate $\mathrm{pH}$ for optimal water treatment and the comfort of swimmers (WHO 2006).

Many studies have been conducted on swimming-water quality in different parts of the world. In Nigeria, Omoni et al. (2019) found that most of the physiochemical parameters analysed were within the recommended limits, except for residual chlorine, turbidity, dissolved oxygen, and total dissolved solids, which exceeded the permissible limit in swimming pools both before and after swimming, while two of the swimming pools studied increased in total coliforms $(150 \%$ and $86 \%)$ and faecal coliform (105\% and $22 \%)$ after swimming. In Ghana, Addo et al. (2018) found that the mean residual chlorine was significantly higher in the $\mathrm{VH}$ pool $(1.357 \pm 1.09)$ than the SH $(0.353 \pm 0.45)$ and RS $(0.95 \pm$ 0.93 ) pools, while the total coliforms, total dissolved solids (TDSs), and $\mathrm{pH}$ were within acceptable limits.

Ferres et al. (2016) found the mean values of residual chlorine and $\mathrm{pH}$ to be outside the recommended ranges, while the other physiochemical parameters, such as dissolved solids, turbidity, and electrical conductivity, were within established sanitary standards. The microbiological test showed that $30 \%$ of the pools tested had an average value for heterotrophic organisms of $107 \mathrm{CFU} / \mathrm{mL}$, higher than the limits set by Venezuelan law. Of the pools studied, $75 \%$ and $60 \%$ presented at least one positive test tube for total and faecal coliforms, respectively.

Fadaei et al. (2013) found that the values of biological parameters for the swimming pools they tested, such as total faecal coliform, Escherichia coli, Legionella, Pseudomonas and heterotrophic organisms, exceeded the guidelines, except for Staphylococcus aureus. While the correlation coefficient between the swimmer's load and the total faecal coliforms and heterotrophic bacteria was (0.949), the turbidity, free residual chlorine, and hardness of all the swimming pools were out of compliance with the standard guidelines.

Bilahac et al. (2012) analysed the free chlorine, $\mathrm{pH}$, and some microbiological parameters in indoor pool waters in hotels. According to the results, $82.8 \%$ of their samples were microbiologically unacceptable, with free chlorine levels below $0.2 \mathrm{mg} / \mathrm{L}$. They suggested that to reduce microbial risks to an acceptable level, the level of free chlorine above $0.2 \mathrm{mg} / \mathrm{L}$.

Sagarat et al. (2012) investigated the water quality of swimming pools in Amman, Jordan. They found that the major inorganic chemical composition $\left(\mathrm{HOC}_{3}{ }^{-}, \mathrm{Cl}^{-}, \mathrm{NO}_{3}{ }^{-}\right.$, $\mathrm{SO}_{4}{ }^{2-}, \mathrm{Ca}^{2+}, \mathrm{Na}^{+}$, and $\mathrm{PO}_{4}{ }^{3-}$ ), BOD and COD was acceptable according to both Jordanian and WHO standards.

The present study was performed to determine the microbiology quality as well as some physical and chemical quality parameters of the water of swimming pools of Mafraq City, Jordan. The objective was to identify whether the

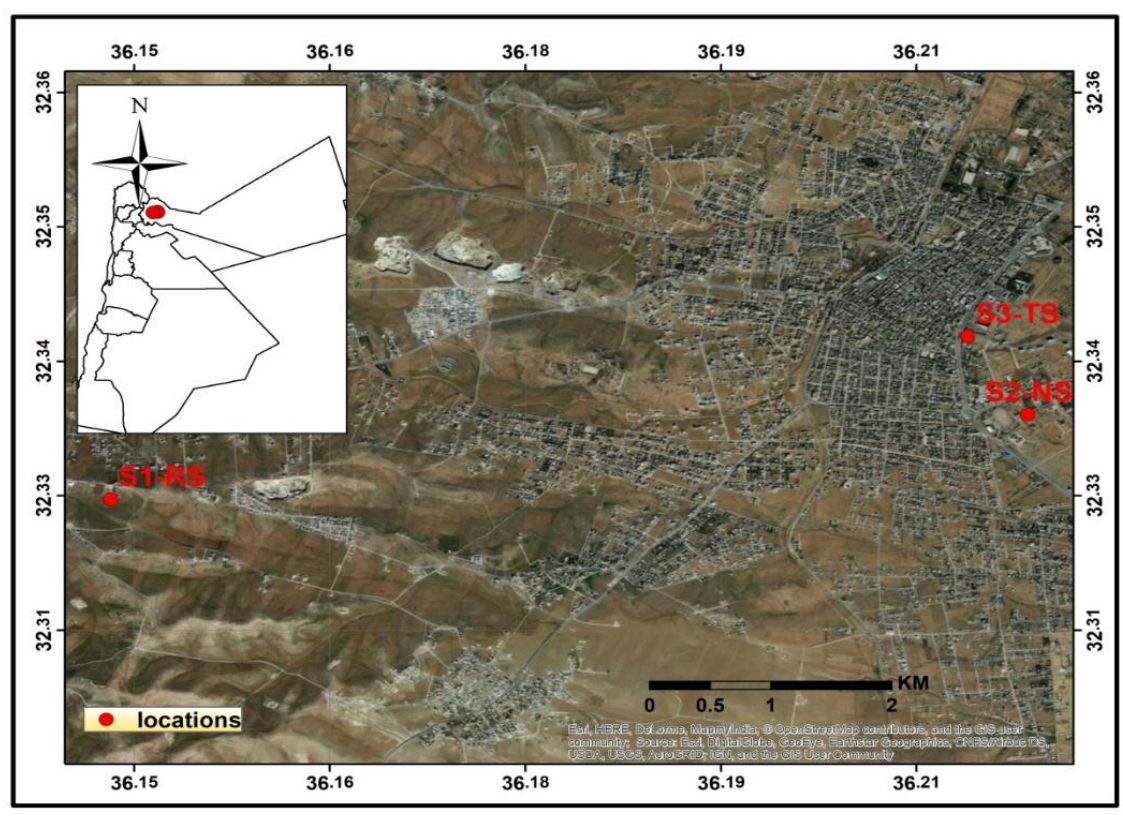

Fig. 1: Location of the study area. 
swimming pools complied with WHO and Jordanian water standards (JS1526/2004). This study will provide an initial collection of data about the quality of public swimming pools in Mafraq and examine the risk factors associated with using these pools. This study is an attempt to recommend reformatory measures to safeguard swimmers from the health risks associated with swimming in unsterilized pools.

\section{MATERIALS AND METHODS}

\section{Study Area}

The study area is located in the city of Mafraq in northern Jordan (Fig. 1). Sampling was done of the three pools most used by swimmers of different ages: Areef (SW1), Teachers' Club (SW2), and Anakeel (SW3). These pools are supplied with high quality potable groundwater from the Amman-Zarqa Basin. The swimming pools are supplied with water at the beginning of the summer once without change, with more water added if the water level in the pools is reduced due to evaporation resulting from high temperatures in the study area, which during summer sometimes exceed $40^{\circ} \mathrm{C}$.

Samples of pool water were collected twice a day after disinfection, once at $7 \mathrm{AM}$, before swimming activities begin, and once at $7 \mathrm{PM}$, when swimming activities end. Water sampling was done using two types of container: a $250 \mathrm{~mL}$ glass container for the microbiological test and a $1 \mathrm{~L}$ polyethylene container for the physical and chemical tests. The samples were collected below the water surface and placed in cold storage $\left(4-10^{\circ} \mathrm{C}\right)$ immediately after collection. The samples were transported to the Institute of Earth and Environment Sciences Laboratories at Al al-Bayt University and analysed within 24 hours.

\section{Physical and Chemical Analyses}

Tables 1 and 2 show the physical and chemical characteristics of the studied swimming pools before and after swimming.
The analyses included temperature $\left({ }^{\circ} \mathrm{C}\right)$, dissolved oxygen (DO, mg/L), electrical conductivity (EC, $\mu \mathrm{S} / \mathrm{cm}$ ), and $\mathrm{pH}$ and salinity, which were measured on-site using a WTW conductivity meter (Multi3320). Residual chlorine and total organic carbon (TOC) were determined by a spectrophotometer 7600 (DIN EN ISO 7393-2 and DIN38402A51), respectively. Trihalomethane (THM) samples were analysed using Gas Chromatography (Trace-GC). The major cations, such as total hardness $(\mathrm{TH})$ and $\mathrm{Ca}^{2+}$, were measured using the EDTA titrimetric method, and $\mathrm{Mg}^{2+}$ by calculation. $\mathrm{Na}^{+}$ and $\mathrm{K}^{+}$were determined using a flame photometer. $\mathrm{Cl}^{-}$and $\mathrm{HCO}_{3}{ }^{-}$were measured with silver nitrate and sulfuric acid titrimetric method, respectively. $\mathrm{NO}_{3}{ }^{-}, \mathrm{SO}_{4}{ }^{2-}$ and $\mathrm{PO}_{4}{ }^{3-}$ were analysed using an ultraviolet spectrometric method. Heavy metals, such as $\mathrm{Mn}, \mathrm{Zn}, \mathrm{Cu}, \mathrm{Cr}$ and $\mathrm{Pb}$, were measured using an Inductivity Coupled Plasma ICP-OES (Perkin Elmer). Preparation and measurements were performed according to standard methods (APHA 2005).

\section{Biological Analysis}

Microbiological contamination using defined substrate technology detected the presence of total coliforms, Escherichia, and Pseudomonas per $100 \mathrm{~mL}$. Total coliforms, Escherichia coli and Pseudomonas were determined using the Coliler-18 (Quanti-Tray/2000) and Pseudalert ${ }^{\circledR}$ (Quanti-Tray/2000) methods, respectively, according to the manufacturer's instructions.

\section{RESULTS AND DISCUSSION}

\section{Physical and Chemical Parameters of the Swimming Pools}

From Table 1 and Fig. 2, it can be seen that the mean temperature of the swimming pools' water samples was within the acceptable limits set by JS and WHO of $21-32^{\circ} \mathrm{C}$; it ranged from $24.4^{\circ} \mathrm{C}$ to $26.3^{\circ} \mathrm{C}$ before swimming and $26.3^{\circ} \mathrm{C}$ to $26.7^{\circ} \mathrm{C}$ after swimming.

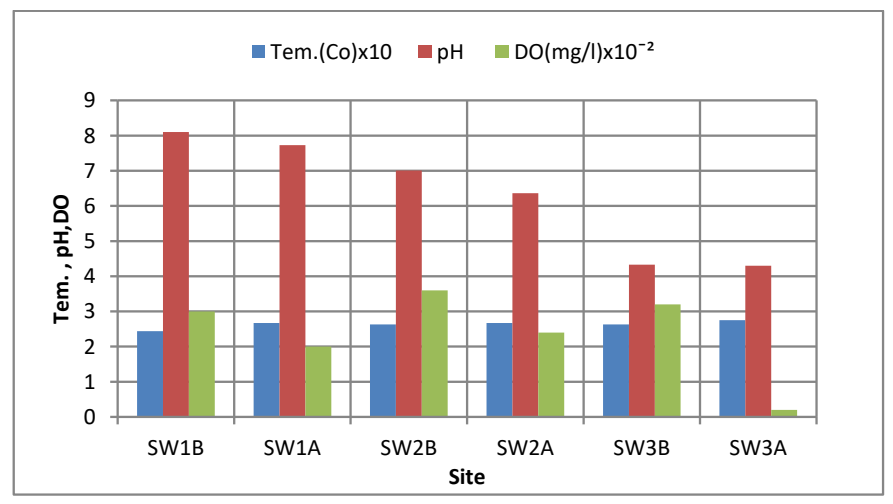

Fig. 2: Temperature $\left({ }^{\circ} \mathrm{C}\right), \mathrm{pH}$, and $\mathrm{DO}(\mathrm{mg} / \mathrm{L})$. 
Table 1: Mean values and standard deviations of physical and chemical characteristics of the studied swimming pools before and after swimming.

\begin{tabular}{|c|c|c|c|c|c|c|c|c|}
\hline Parameters & & SW1B & SW1A & SW2B & SW2A & SW3B & SW3A & $\begin{array}{l}\text { JS and } \\
\text { WHO }\end{array}$ \\
\hline $\begin{array}{l}\text { Tempera- } \\
\text { ture } \\
\left({ }^{\circ} \mathrm{C}\right)\end{array}$ & $\begin{array}{l}\text { Max. } \\
\text { Min. } \\
\text { Mean } \pm \text { SD }\end{array}$ & $\begin{array}{l}25 \\
24 \\
24.4 \pm 0.42\end{array}$ & $\begin{array}{l}27.3 \\
25.9 \\
26.7 \pm 0.62\end{array}$ & $\begin{array}{l}26.7 \\
25.6 \\
26.3 \pm 0.46\end{array}$ & $\begin{array}{l}28.8 \\
25.9 \\
26.7 \pm 1.21\end{array}$ & $\begin{array}{l}27.3 \\
25 \\
26.3 \pm 1.08\end{array}$ & $\begin{array}{l}28.3 \\
27 \\
27.5 \pm 0.52\end{array}$ & $22-29$ \\
\hline $\mathrm{pH}$ & $\begin{array}{l}\text { Max. } \\
\text { Min. } \\
\text { Mean } \pm \text { SD }\end{array}$ & $\begin{array}{l}8.71 \\
7.76 \\
8.1 \pm .37\end{array}$ & $\begin{array}{l}8.06 \\
7.74 \\
7.73 \pm 0.13\end{array}$ & $\begin{array}{l}7.82 \\
4.22 \\
7.01 \pm 1.57\end{array}$ & $\begin{array}{l}7.81 \\
3.48 \\
6.36 \pm 1.60\end{array}$ & $\begin{array}{l}4.95 \\
4.14 \\
4.33 \pm 0.44\end{array}$ & $\begin{array}{l}4.6 \\
4.0 \\
4.3 \pm 0.25\end{array}$ & $7.2-7.8$ \\
\hline $\begin{array}{l}\text { Dissolved } \\
\mathrm{O}_{2}(\mathrm{mg} / \mathrm{L})\end{array}$ & $\begin{array}{l}\text { Max. } \\
\text { Min. } \\
\text { Mean } \pm \text { SD }\end{array}$ & $\begin{array}{l}2.04 \\
0.02 \\
2.03 \pm 0.007\end{array}$ & $\begin{array}{l}1.03 \\
0.02 \\
1.02 \pm 0.006\end{array}$ & $\begin{array}{l}3.07 \\
0.02 \\
3.036 \pm 0.02\end{array}$ & $\begin{array}{l}1.03 \\
0.02 \\
1.024 \pm 0.006\end{array}$ & $\begin{array}{l}2.06 \\
0.03 \\
2.032 \pm 0.005\end{array}$ & $\begin{array}{l}0.03 \\
0.02 \\
0.0023 \pm 0.005\end{array}$ & 5 \\
\hline $\begin{array}{l}\mathrm{EC} \\
(\mu \mathrm{S} / \mathrm{cm})\end{array}$ & $\begin{array}{l}\text { Max. } \\
\text { Min. } \\
\text { Mean } \pm \text { SD }\end{array}$ & $\begin{array}{l}1179 \\
1025 \\
1075 \pm 64\end{array}$ & $\begin{array}{l}1635 \\
1038 \\
1217 \pm 259\end{array}$ & $\begin{array}{l}1421 \\
1087 \\
1189 \pm 138\end{array}$ & $\begin{array}{l}1710 \\
1086 \\
1312 \pm 260\end{array}$ & $\begin{array}{l}2900 \\
2030 \\
2314 \pm 343\end{array}$ & $\begin{array}{l}3190 \\
2050 \\
2453 \pm 460\end{array}$ & \\
\hline $\begin{array}{l}\text { Salinity } \\
(\mathrm{mg} / \mathrm{L})\end{array}$ & $\begin{array}{l}\text { Max. } \\
\text { Min. } \\
\text { Mean } \pm \text { SD }\end{array}$ & $\begin{array}{l}358.6 \\
268.97 \\
310.6 \pm 40\end{array}$ & $\begin{array}{l}576.4 \\
301 \\
376.5 \pm 114\end{array}$ & $\begin{array}{l}473.9 \\
320.21 \\
389.1 \pm 70\end{array}$ & $\begin{array}{l}589.2 \\
326.6 \\
431.6 \pm 113\end{array}$ & $\begin{array}{l}813.3 \\
525.2 \\
658 \pm 118\end{array}$ & $\begin{array}{l}1056.6 \\
595.6 \\
765.9 \pm 182\end{array}$ & \\
\hline $\begin{array}{l}\text { Residual } \\
\text { Chlorine } \\
(\mathrm{mg} / \mathrm{L})\end{array}$ & $\begin{array}{l}\text { Max. } \\
\text { Min. } \\
\text { Mean } \pm \text { SD }\end{array}$ & $\begin{array}{l}2.59 \\
0.15 \\
0.998 \pm 1.16\end{array}$ & $\begin{array}{l}2.21 \\
0.09 \\
0.873 \pm 1.04\end{array}$ & $\begin{array}{l}3.8 \\
0.11 \\
1.26 \pm 3.4\end{array}$ & $\begin{array}{l}3.13 \\
0.05 \\
1 \pm 1.3\end{array}$ & $\begin{array}{l}0.5 \\
0.12 \\
0.26 \pm 0.13\end{array}$ & $\begin{array}{l}0.16 \\
0.05 \\
0.117 \pm 0.03\end{array}$ & $1-3$ \\
\hline $\begin{array}{l}\text { TOC } \\
(\mathrm{mg} / \mathrm{L})\end{array}$ & $\begin{array}{l}\text { Max. } \\
\text { Min. } \\
\text { Mean } \pm \text { SD }\end{array}$ & $\begin{array}{l}85.3 \\
30.2 \\
45.82 \pm 22.7\end{array}$ & $\begin{array}{l}47.1 \\
19.6 \\
28.76 \pm 10.9\end{array}$ & $\begin{array}{l}83.5 \\
27.7 \\
54.86 \pm 26.2\end{array}$ & $\begin{array}{l}83.1 \\
18.8 \\
41.26 \pm 25.3\end{array}$ & $\begin{array}{l}80.1 \\
20.2 \\
42.26 \pm 23.8\end{array}$ & $\begin{array}{l}50.5 \\
30.2 \\
39.2 \pm 7.3\end{array}$ & \\
\hline $\begin{array}{l}\text { THM } \\
(\mathrm{mg} / \mathrm{L})\end{array}$ & $\begin{array}{l}\text { Max. } \\
\text { Min. } \\
\text { Mean } \pm \text { SD }\end{array}$ & $\begin{array}{l}0.07 \\
0.053 \\
0.062 \pm 0.012\end{array}$ & $\begin{array}{l}0.054 \\
0.052 \\
0.053 \pm 0.001\end{array}$ & $\begin{array}{l}0.054 \\
0.053 \\
0.054 \pm 0.001\end{array}$ & $\begin{array}{l}0.052 \\
0.049 \\
0.051 \pm 0.002\end{array}$ & $\begin{array}{l}0.047 \\
0.042 \\
0.045 \pm 0.004\end{array}$ & $\begin{array}{l}0.038 \\
0.034 \\
0.036 \pm 0.003\end{array}$ & 0.15 \\
\hline $\mathrm{Na}^{+}(\mathrm{mg} / \mathrm{L})$ & $\begin{array}{l}\text { Max. } \\
\text { Min. } \\
\text { Mean } \pm \text { SD }\end{array}$ & $\begin{array}{l}187.8 \\
131.8 \\
152.3 \pm 21.1\end{array}$ & $\begin{array}{l}249.9 \\
139.6 \\
171.9 \pm 52.2\end{array}$ & $\begin{array}{l}148.6 \\
129.6 \\
138.7 \pm 8.6\end{array}$ & $\begin{array}{l}143.6 \\
136.6 \\
139.3 \pm 3.4\end{array}$ & $\begin{array}{l}313.1 \\
249.9 \\
277.3 \pm 27.8\end{array}$ & $\begin{array}{l}315.1 \\
251.9 \\
284.8 \pm 32.5\end{array}$ & $200-300$ \\
\hline $\mathrm{K}^{+}(\mathrm{mg} / \mathrm{L})$ & $\begin{array}{l}\text { Max. } \\
\text { Min. } \\
\text { Mean } \pm \text { SD }\end{array}$ & $\begin{array}{l}18.2 \\
14.8 \\
16.3 \pm 3\end{array}$ & $\begin{array}{l}18.4 \\
15.5 \\
17.3 \pm 1.2\end{array}$ & $\begin{array}{l}9.9 \\
6.5 \\
7.9 \pm 1.5\end{array}$ & $\begin{array}{l}15.3 \\
5.8 \\
9.1 \pm 3.9\end{array}$ & $\begin{array}{l}17.7 \\
14.0 \\
15.7 \pm 1.8\end{array}$ & $\begin{array}{l}21.7 \\
14.3 \\
17.5 \pm 3.3\end{array}$ & 12 \\
\hline $\begin{array}{l}\mathrm{Ca}^{2+} \\
(\mathrm{mg} / \mathrm{L})\end{array}$ & $\begin{array}{l}\text { Max. } \\
\text { Min. } \\
\text { Mean } \pm \text { SD }\end{array}$ & $\begin{array}{l}155.0 \\
93.8 \\
108.5 \pm 27.9\end{array}$ & $\begin{array}{l}148.9 \\
53.0 \\
115.8 \pm 43.2\end{array}$ & $\begin{array}{l}138.7 \\
57.1 \\
103.6 \pm 34.6\end{array}$ & $\begin{array}{l}130.6 \\
69.4 \\
111.2 \pm 28.1\end{array}$ & $\begin{array}{l}142.8 \\
106.1 \\
126.5 \pm 15.3\end{array}$ & $\begin{array}{l}163.2 \\
110.2 \\
137.9 \pm 21.5\end{array}$ & 250 \\
\hline $\begin{array}{l}\mathrm{Mg}^{2+} \\
(\mathrm{mg} / \mathrm{L})\end{array}$ & $\begin{array}{l}\text { Max. } \\
\text { Min. } \\
\text { Mean } \pm \text { SD }\end{array}$ & $\begin{array}{l}31.6 \\
2.4 \\
13.6 \pm 11.6\end{array}$ & $\begin{array}{l}36.5 \\
4.9 \\
14.9 \pm 14.5\end{array}$ & $\begin{array}{l}46.2 \\
12.2 \\
23.7 \pm 16.0\end{array}$ & $\begin{array}{l}38.9 \\
2.4 \\
25.8 \pm 24.9\end{array}$ & $\begin{array}{l}51.03 \\
24.3 \\
36.5 \pm 11.0\end{array}$ & $\begin{array}{l}60.75 \\
24.3 \\
42.5 \pm 14.8\end{array}$ & 250 \\
\hline $\mathrm{Cl}^{-}(\mathrm{mg} / \mathrm{L})$ & $\begin{array}{l}\text { Max. } \\
\text { Min. } \\
\text { Mean } \pm \text { SD }\end{array}$ & $\begin{array}{l}198.5 \\
148.9 \\
171.9 \pm 22.1\end{array}$ & $\begin{array}{l}319.1 \\
166.6 \\
214.5 \pm 71.0\end{array}$ & $\begin{array}{l}262.3 \\
177.3 \\
215.4 \pm 38.5\end{array}$ & $\begin{array}{l}326.1 \\
180.8 \\
238.9 \pm 62.7\end{array}$ & $\begin{array}{l}450.2 \\
290.7 \\
364.2 \pm 65.6\end{array}$ & $\begin{array}{l}584.9 \\
329.7 \\
424 \pm 100.5\end{array}$ & 500 \\
\hline $\begin{array}{l}\mathrm{HCO}_{3}^{-} \\
(\mathrm{mg} / \mathrm{L})\end{array}$ & $\begin{array}{l}\text { Max. } \\
\text { Min. } \\
\text { Mean } \pm \text { SD }\end{array}$ & $\begin{array}{l}171.0 \\
97.6 \\
128.2 \pm 30.8\end{array}$ & $\begin{array}{l}158.8 \\
73.2 \\
129.4 \pm 38.2\end{array}$ & $\begin{array}{l}183.21 \\
109.9 \\
150.6 \pm 37.3\end{array}$ & $\begin{array}{l}158.8 \\
146.6 \\
154.7 \pm 7.1\end{array}$ & Not found & Not found & \\
\hline $\begin{array}{l}\mathrm{NO}_{3}^{-} \\
(\mathrm{mg} / \mathrm{L})\end{array}$ & $\begin{array}{l}\text { Max. } \\
\text { Min. } \\
\text { Mean } \pm \text { SD }\end{array}$ & $\begin{array}{l}35.6 \\
20.6 \\
26.0 \pm 6.6\end{array}$ & $\begin{array}{l}24.6 \\
3.7 \\
18.3 \pm 8.5\end{array}$ & $\begin{array}{l}27.37 \\
24.2 \\
25.7 \pm 1.32\end{array}$ & $\begin{array}{l}27.8 \\
5.6 \\
22.2 \pm 9.3\end{array}$ & $\begin{array}{l}39.6 \\
34.9 \\
37.0 \pm 2.2\end{array}$ & $\begin{array}{l}37.9 \\
5.97 \\
30.5 \pm 13.8\end{array}$ & 50 \\
\hline $\begin{array}{l}\mathrm{SO}_{4}{ }^{2-} \\
(\mathrm{mg} / \mathrm{L})\end{array}$ & $\begin{array}{l}\text { Max. } \\
\text { Min. } \\
\text { Mean } \pm \text { SD }\end{array}$ & $\begin{array}{l}24.8 \\
12.7 \\
16.9 \pm 6.8\end{array}$ & $\begin{array}{l}24.8 \\
14.9 \\
18.2 \pm 5.7\end{array}$ & $\begin{array}{l}16.8 \\
10.1 \\
13.4 \pm 3.4\end{array}$ & $\begin{array}{l}17.16 \\
10.31 \\
13.6 \pm 3.4\end{array}$ & $\begin{array}{l}29.5 \\
10.8 \\
21.8 \pm 9.8\end{array}$ & $\begin{array}{l}31.14 \\
10.87 \\
22.7 \pm 10.5\end{array}$ & 500 \\
\hline $\begin{array}{l}\mathrm{PO}_{4}^{3-} \\
(\mathrm{mg} / \mathrm{L})\end{array}$ & $\begin{array}{l}\text { Max. } \\
\text { Min. } \\
\text { Mean } \pm \text { SD }\end{array}$ & $\begin{array}{l}0.092 \\
0.009 \\
0.044 \pm 0.038\end{array}$ & $\begin{array}{l}0.391 \\
0.049 \\
0.12 \pm 0.149\end{array}$ & $\begin{array}{l}0.194 \\
0.076 \\
0.011 \pm 0.056\end{array}$ & $\begin{array}{l}0.671 \\
0.082 \\
0.275 \pm 0.236\end{array}$ & $\begin{array}{l}0.403 \\
0.112 \\
0.219 \pm 0.14\end{array}$ & $\begin{array}{l}0.342 \\
0.086 \\
0.209 \pm 0.113\end{array}$ & 0.03 \\
\hline
\end{tabular}


One of the most important items to test in swimming water is $\mathrm{pH}$. The mean values of the swimming pools' water ranged between 4.33 in SW3 and 8.1 in SW1 before swimming and from 4.3 in SW3 to 7.73 in SW1 after swimming (Fig. 2). The $\mathrm{pH}$ for SW1B, SW2A, and SW3 was not within the recommended standard of 7.2-7.8. All pH values for SW3 were less than 5 , due to excessive chlorination resulting from using trichloroisocyanuric acid $\left(\mathrm{C}_{3} \mathrm{Cl}_{3} \mathrm{~N}_{3} \mathrm{O}_{3}\right)$ in the disinfection process; the trichloroisocyanuric acid raised the acidity of the water. It was found that the soda ash $\left(\mathrm{Na}_{2} \mathrm{CO}_{3}\right)$ used to neutralize the $\mathrm{pH}$ was insufficient, causing burns on the skin of some children who used this pool (Fig. 3). It was noted during sample collection that the managers of SW3 evacuated the pool and disinfected the water every 3 hours, which in turn affected the health of the pool users.

Dissolved oxygen is probably the most critical quality parameter in swimming-pool water. The DO level can indicate how polluted the water is and how well it can support aquatic plant and animal life (Omoni et al. 2019). The DO content was significantly lower than the acceptable standard (7.5 mg/L); it ranged between $2.03 \mathrm{mg} / \mathrm{L}$ and 3.036 $\mathrm{mg} / \mathrm{L}$ before swimming and between $0.0023 \mathrm{mg} / \mathrm{L}$ and 1.024 $\mathrm{mg} / \mathrm{L}$ after swimming (Fig. 2). This reduction is due to its consumption by bacteria, which decompose the organic pollutants in swimming pools. Generally, a higher DO level indicates better water quality and healthier sampled pools. The depletion of DO in water could facilitate the microbial conversion of nitrates (WHO 2008), and a low level of DO in pool water is not healthy for humans.

Fig. 4 shows the mean values of EC and salinity. The mean value of EC ranged between $1075 \mu \mathrm{S} / \mathrm{cm}$ and $2314 \mu \mathrm{S} /$ $\mathrm{cm}$ before swimming and between $1217 \mu \mathrm{S} / \mathrm{cm}$ and $2453 \mu \mathrm{S} /$ $\mathrm{cm}$ after swimming. The mean value of the salinity ranged between $310.6 \mathrm{mg} / \mathrm{L}$ and $658.12 \mathrm{mg} / \mathrm{L}$ before swimming and between $376.5 \mathrm{mg} / \mathrm{L}$ and $765.9 \mathrm{mg} / \mathrm{L}$ after swimming. These values are within the permissible limits set by JS and WHO, except for SW3, which exceeded the recommended standards due to the high percentage of dissolved salt in the water and the addition of pollutants from swimmers.

Table 1 and Fig. 5 show the residual level of chlorine concentration before swimming, which is higher than the level after swimming. The mean values of the residual chlorine ranged between 0.26 and $2.26 \mathrm{mg} / \mathrm{L}$ before swimming and

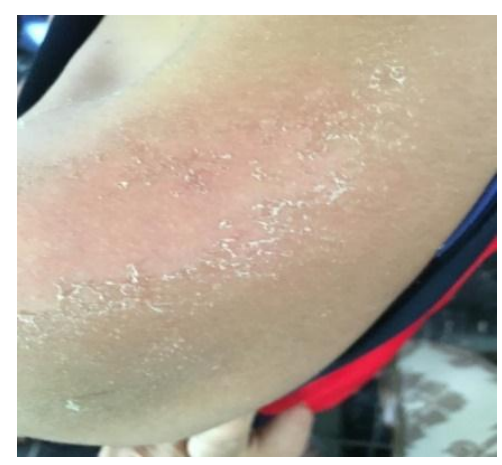

Fig. 3: Burns on the bodies of some children attending SW3.

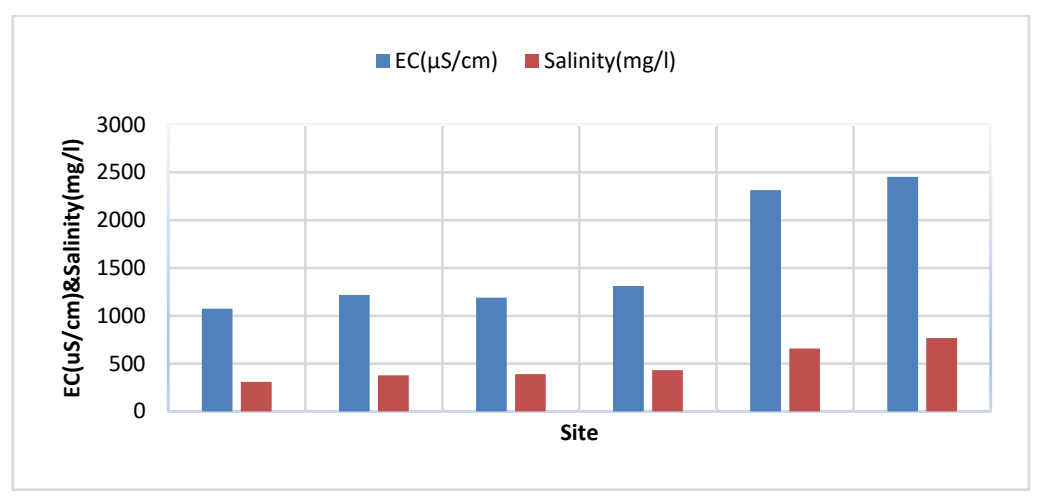

Fig. 4: EC ( $\mu \mathrm{S} / \mathrm{cm})$ and salinity $(\mathrm{mg} / \mathrm{L})$. 
between 0.117 and $1 \mathrm{mg} / \mathrm{L}$ after swimming. The results show that the mean residual chlorine was significantly higher in SW2 than in the other pools (SW1 and SW3). The obtained results were within the standards set by WHO and JS. In this study, the main reason for low residual chlorine is the consumption of chlorine in killing microbes in the water and its interaction with organic substances, forming undesirable compounds, such as THMs and HAAs.

Swimming pools must be disinfected to prevent the spread of disease among swimmers and the unwanted growth of bacteria and algae. When chlorine comes into contact with organic matter, it may result in the production of undesirable and dangerous substances for human health and the environment, such as THMs (chloroform, bromodichloromethane, dibromochloromethane and bromoform) and HAAs. In this study, the mean concentration of TOC before swimming ranged between $39.2 \mathrm{mg} / \mathrm{L}$ and $54.86 \mathrm{mg} / \mathrm{L}$, and of THMs between $0.045 \mathrm{mg} / \mathrm{L}$ and 0.062 $\mathrm{mg} / \mathrm{L}$, and after swimming ranged between $28.7 \mathrm{mg} / \mathrm{L}$ and
$41.26 \mathrm{mg} / \mathrm{L}$ and between $0.036 \mathrm{mg} / \mathrm{L}$ and $0.053 \mathrm{mg} / \mathrm{L}$, respectively (Fig. 5). Because it is an indoor pool, SW1 showed a higher concentration of THMs than did other pools, but no pool exceeded permissible limits, as most of the chlorine was used to remove pathogens and react with TOC to form THM and HAA compounds. THMs are naturally volatile and can evaporate from the water, a process that depends on several factors, including their concentration in the water, the temperature, the amount of splashing, and surface disturbance (WHO 2006). As shown in Fig. 5, THMs increased with acidity, due to a longer reaction time and higher chlorination dosage (Wang et al. 2015). Potential THM formation increases with the concentration of TOC. The yield of THMs increased with $\mathrm{pH}$, which ranged from 5 to 10 (Wang et al. 2015). This was inconsistent with the observations of other researchers (Zhang et al. 2010).

TH, $\mathrm{Ca}^{2+}, \mathrm{Mg}^{2+}, \mathrm{K}^{+}, \mathrm{Na}^{+}, \mathrm{Cl}^{-}, \mathrm{HCO}_{3}{ }^{-} \mathrm{NO}_{3}{ }^{-}$and $\mathrm{SO}_{4}{ }^{2-}$ in all pools were within the recommended standards; $\mathrm{HCO}_{3}{ }^{-}$was

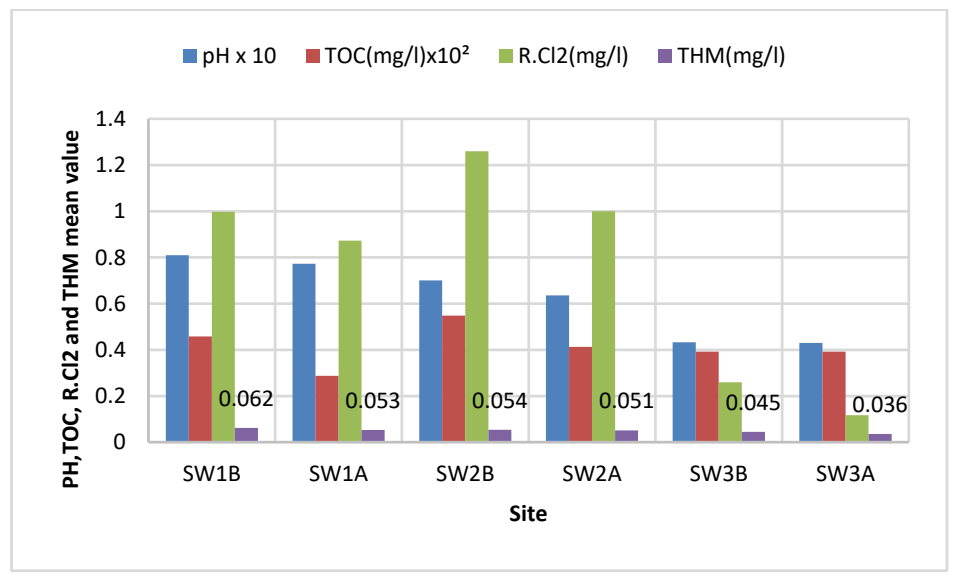

Fig. 5: Mean pH and mean concentrations of TOC, Residual chlorine and THM (mg/L).

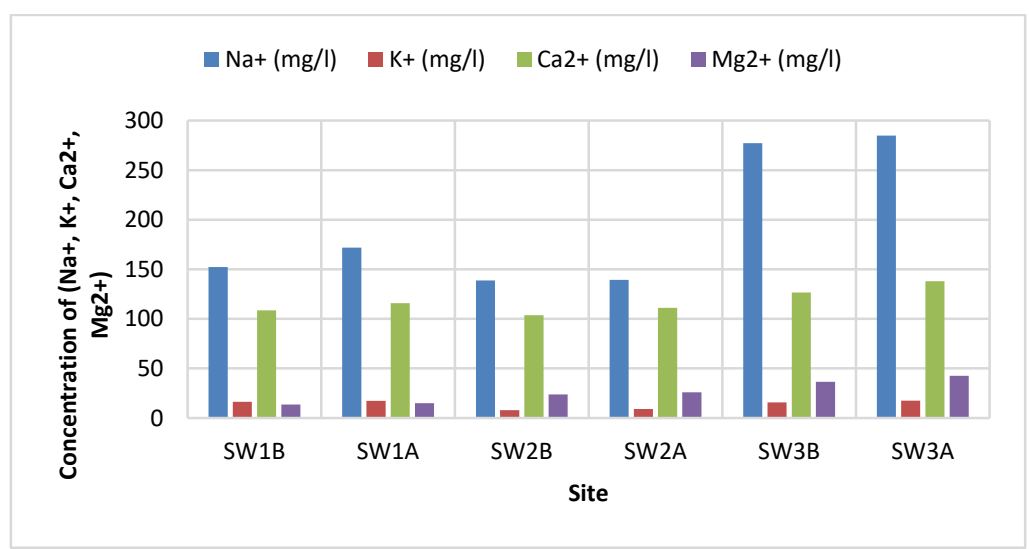

Fig. 6: Concentration of $\mathrm{Na}^{+}, \mathrm{K}^{+}, \mathrm{Ca}^{2+}$ and $\mathrm{Mg}^{2+}(\mathrm{mg} / \mathrm{L})$. 


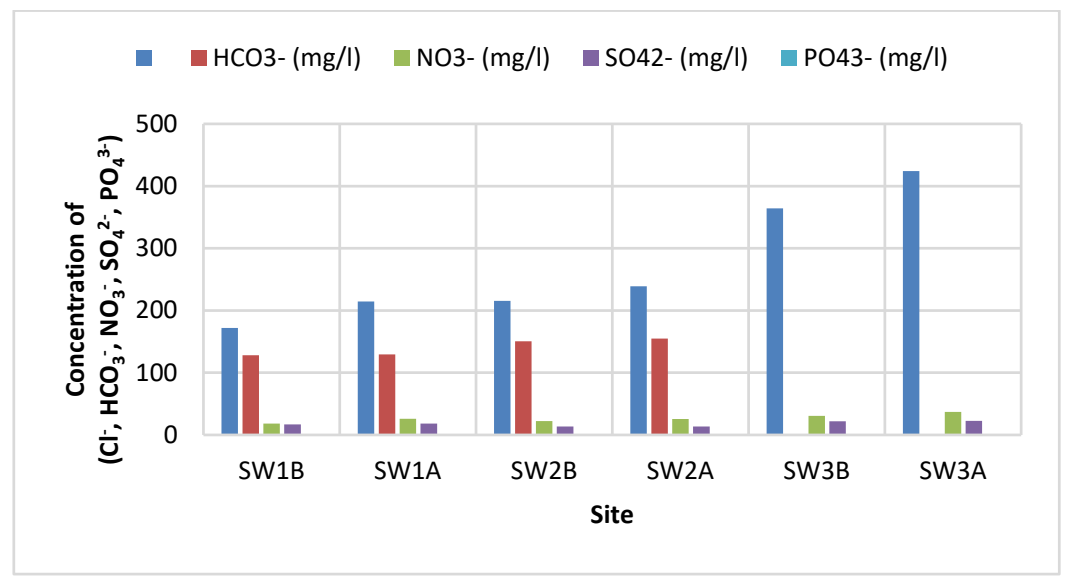

Fig. 7: Concentration of $\mathrm{Cl}^{-}, \mathrm{HCO}_{3}{ }^{-}, \mathrm{NO}_{3}{ }^{-}, \mathrm{SO}_{4}{ }^{2-}$, and $\mathrm{PO}_{4}{ }^{-3}(\mathrm{mg} / \mathrm{L})$.

Table 2: Mean concentrations of the measured heavy metals (DL: Detection limit).

\begin{tabular}{|llllllll|}
\hline Parameter & SW1B & SW1A & SW2B & SW2A & SW3B & SW3A \\
\hline $\mathrm{B}(\mathrm{mg} / \mathrm{L})$ & $<\mathrm{DL}$ & $<\mathrm{DL}$ & $<\mathrm{DL}$ & 0.127 & 0.098 & 0.177 & JS\&WHO \\
$\mathrm{Mn}(\mathrm{mg} / \mathrm{L})$ & 0.033 & 0.015 & $<\mathrm{DL}$ & $<\mathrm{DL}$ & 0.019 & 0.018 & 0.1 \\
$\mathrm{Zn}(\mathrm{mg} / \mathrm{L})$ & $<\mathrm{DL}$ & $<\mathrm{DL}$ & 0.036 & 0.061 & 1.018 & 0.665 & 4 \\
$\mathrm{Cu}(\mathrm{mg} / \mathrm{L})$ & 0.0227 & 0.027 & 0.038 & 0.103 & 0.031 & 0.034 & 0.032 \\
$\mathrm{Cr}(\mathrm{mg} / \mathrm{L})$ & 0.01 & 0.009 & 0.033 & 0.004 & $<\mathrm{DL}$ & $<.05$ \\
$\mathrm{~Pb}(\mathrm{mg} / \mathrm{L})$ & $<\mathrm{DL}$ & $<\mathrm{DL}$ & $<\mathrm{DL}$ & $<\mathrm{DL}$ & $<\mathrm{DL}$ & $<\mathrm{DL}$ & 0.01 \\
\hline
\end{tabular}

not. The concentration of $\mathrm{HCO}_{3}{ }^{-}$was zero in $\mathrm{SW} 3$ because the mean value of its $\mathrm{pH}$ was less than 5 both before and after swimming. This study shows that the concentration of $\mathrm{PO}_{4}{ }^{3-}$ was higher than the recommended standards $(<0.03$ $\mathrm{mg} / \mathrm{L}$ ) in both $\mathrm{SW} 1$ and $\mathrm{SW} 3$ both before and after swimming (Table 1 and Figs. 6 and 7).

Table 2 shows the concentration of heavy metals B, Mn, $\mathrm{Zn}, \mathrm{Cu}, \mathrm{Cr}$ and $\mathrm{Pb}$. All mean values measured were lower than the recommended standards for water used for drinking and recreation.

\section{Microbiological Parameters}

The results of the study indicate that the swimming water improved in total coliform, Escherichia and Pseudomonas before and after swimming due to the effectiveness of the disinfection process and compliance with JS and WHO $<1 / 100 \mathrm{~mL}$.

\section{CONCLUSIONS}

Our study has provided information on the quality of the swimming water in some selected swimming pools in Mafraq City in Northern Jordan. Most parameters tested in SW3 did not meet the Jordanian or WHO standards for the physical and chemical quality of swimming pools, but most physical and chemical parameters in SW1 and SW2 were found to be within the permissible limits of both sets of standards. The microbiological loads of all the swimming pools, however, were acceptable according to both Jordanian and WHO standards. The THMs increase when the $\mathrm{pH}$ increases due to the longer reaction time and higher chlorination dosage.

\section{REFERENCES}

Addo, M., Tee, J. and Larbi, J. 2018. Recreational water quality assessment of some selected swimming pool in Asuogyaman district, Ghana. Microbiology Research Journal International, 26(5): 1-8.

APHA 2005. Standard Methods for the Examination of Water and Wastewater, $20^{\text {ed }}$. American Public Health Association, American Water Works Association and Water Environment Federation. Washington DC.

Bilahac, L., Lusic, D., Jelinic, J. and Rukavina, T. 2012. Microbiological and chemical indicators of water quality in indoor hotel swimming pools before and after training of swimming pool operators. Journal of Water and Health, 10(1): 108-115.

Chowdhury, S., Alhooshanik, K. and Karanfil, T. 2014. Disinfections byproducts in swimming pools: Occurrences, implications and future needs, a review. Water Research, 53: 68-109.

Fadaei, A. and Amiri, M. 2013. Comparison of chemical, biological and physical quality assessment of indoor swimming pools in Shahrekord city, Iran in 2013. Global Journal of Health Science, 7(3): 240-248.

Ferres, S., Colina, C., Morales, P., Torres, R., Castellano, C. and Leal, J. 2016. Physicochemical and microbiological quality of swimming 
pool water of two recreational complexes in Zulia State. Boletin de Malariologiay salnd Ambienta, 2: 202-210.

Hong, H., Yujing, X., Mengyong, R., Fanglei, L., Hongjun, L. and Yan, L. 2012. Factors affecting THMs, HAAs and HNMs formation of Jin Lan reservoir water exposed to chlorine and monochloramine. Science of the Total Environment, 444: 196-204.

https://www.okchem.com/product/nndimethyl2hydroxypropylammoniumchloride-polymer-25988970-201811051257620.html

Lempart, A., Kudlek, E. and Dudziak, M. 2018. Determination of micropollutants in water samples from swimming pool systems. Water, 10: 1083 .

Nemery, B. Hoet, P.M. and Nowak, D. 2002. Indoor swimming pools, water chlorination and respiratory health. Eur. Respir., 19: 790-793.

Nowack, R. and Views, C. 2016. The Chemistry of Pools, copyright: Wiley$\mathrm{VCH}$ Veriag $\mathrm{GmbH} \& \mathrm{CO}$. kGaA Weinheim.

Omoni, V., Torjir, D. and Okekporo, S. 2019. Studies on the physicochemical and bacteriological properties on the semi-public swimming pools in Makurdia, Nigeria, African Journal of Microbiology Research, 13(4): 264-272.

Popadopoulou, C., Economou, V., Sokkas, H., Gousia, P., Giannakopoulos, X. and Dontorou, C. 2008. Microbiological quality of indoor and outdoor (1998-2019). Swimming pools in Greece: Investigation of the antibiotic resistance of the bacterial isolates. Int. J. Hyg. Environ. Health, 211(3-4): 385-97.
Public and Environmental Health Act of Government of Australia 1998. Standard for the Operation of Swimming Pools and Spa Pools in South Australia. Public and Environmental Health Act of Government of Australia.

Sagarat, B., Harahsheh, S. and Jiries, A. 2012. Inorganic chemical composition of swimming pools in Amman-Jordan. Research Journal of Environmental and Earth Sciences, 4(10): 890-849.

Wang, F., Baoyu, G., Defang, M., Ruihua, L., Shenglei, S., Qinyan, Y., Yan, W. and Qian, L. 2016. Effects of operating conditions on trihalomethanes formation and speciation during chloramination in reclaimed water. Environ. Sci. Pollut. Res., 23(2): 1576-1583.

WHO 2006. Guidelines for Safe Recreational Water Environments, Vol. 2, Swimming Pools and Similar Environments. World Health Organization.

Yan, M., Roccaro, P., Fabbricino, M. and Korshin, G. 2018. Comparison of the effects of chloramine and chlorine on the aromaticity of dissolved organic matter and yields of disinfection by-products. Chemosphere, 191: 477-484.

Yang, L., Chene, X., Shef, Q., Caoa, G., Liua, Y., Chang, V. and Tangh, C. 2018. Regulation, formation, exposure, and treatment of disinfection by-products (DBPs) in swimming pool waters: A critical review. Environment International, 121(1039-1057).

Zhang, Y.J., Zhou, L.L., Zeng, G., Song, Z.G. and Li, G.B. 2010. Factors affecting the formation of trihalomethanes in the presence of bromide during chloramination. J. Zhejiang Univ. Sci. A, 11(8): 606-612. 